\title{
The status of the Sumatran rhinoceros in north-eastern India
}

The historical distribution of the Sumatran rhinoceros Dicerorhinus sumatrensis stretched from the foothills of the eastern Himalaya in Bhutan and north-eastern India, through Myanmar and Indo-China to Borneo and Sumatra. However, because of poaching and habitat loss the species is now struggling for survival in a few pockets of Myanmar, Thailand, the Malay peninsula, Sumatra and Borneo (Khan, 1989).

In the Indian subcontinent in the 19th century, the Sumatran rhinoceros occurred in parts of Assam, Nagaland, Manipur, Tripura, Mizoram, northern Bengal, Bhutan, Comilla and the Chittagong Hill Tracts (the latter two areas are now in Bangladesh; Lydekker, 1900; Finn, 1929; Milroy, 1934; Harper, 1945). The last two records for the subcontinent were in 1967, when a Sumatran rhinoceros was killed near Cox's Bazar in the Chittagong area (Cubitt and Mountfort, 1985) and a rhinoceros was seen by local people in the Punikhal area of Sonai Reserved Forest of Cachar district, southern Assam. The latter was probably also a Sumatran rhinoceros because until 1890 this species was once encountered infrequently in the Katakhal and Innerline Reserved Forests of Hailakandi and Cachar districts of southern Assam (A. M. Choudhury, pers. comm.).

The areas closest to India's boundary where the species still occurs are the Lassai tract and Tamanthi Wildlife Sanctuary of northern Myanmar (Tilson and Traylor-Holzer, 1993). A survey in Tamanthi in 1994 revealed the presence of a few individuals (Rabinowitz et al., 1995) and also recorded at least four reports of sightings in the Saramati area close to the India-Myanmar border between 1971 and 1993 (Figure 1).

In January 1996, I traversed the Ukhrul district of Manipur bordering Myanmar, both by road and on foot along tracks on both sides of the roads, to assess the possibility of the occurrence of any Sumatran rhino. In June 1996 I visited Nagaland, where part of Saramati is located, also to determine whether rhinos were present as well as to look for other species of wildlife. I used an illustration of the Indian one-horned rhinoceros Rhinoceros unicornis when interviewing local people about sightings but they explained to me that the animal that occasionally occurs in their area is
Figure 1. Map showing survey routes and recorded localities of the Sumatran rhinoceros in India and nearby areas of Myanmar. The locations in Myanmar are after Rabinowitz et al. (1995).

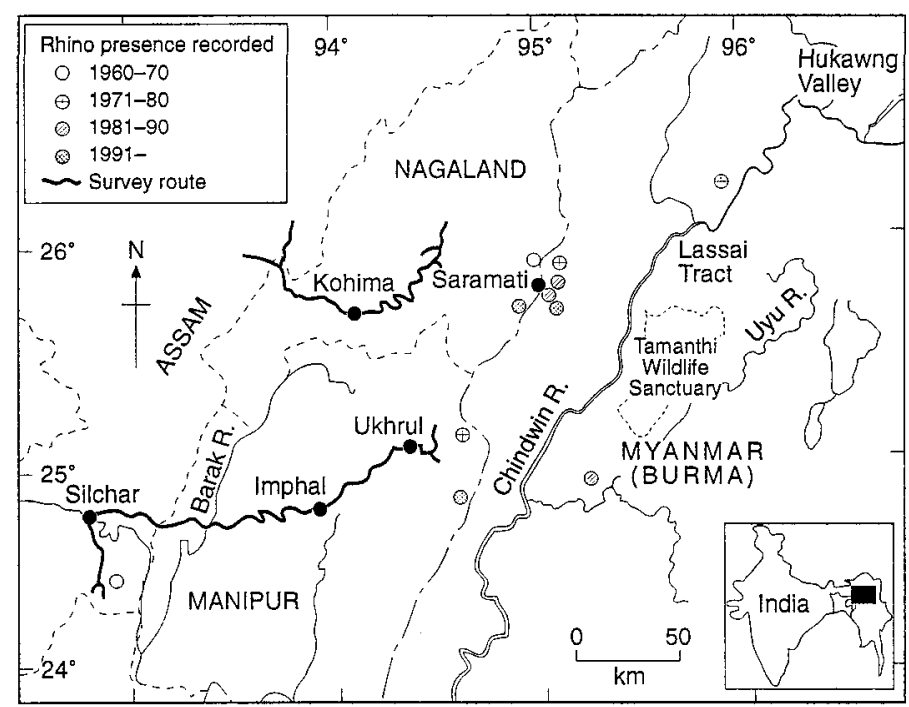

151 
different, being hairy and having two small horns. In Manipur, the Sumatran rhino is occasionally reported from the Anko range of Ukhrul district. Villagers of Konkan (about 88 $\mathrm{km}$ by road south-east of Ukhrul town) encountered stray individuals as recently as the early 1990s (Aleng, pers. comm.). In the 1970s a rhino was shot by the Tangkhul Naga tribe (known as the Somra tribe in Myanmar) of Khamsong village, north-east of Ukhrul town. The Tangkhuls call the animal selho.

In Nagaland there are two specific records, both from the Tuensang district. In 1967-68 a rhino was reported from Saramati on the lower slopes of this 3826-m peak (S. Hukiye, pers. comm.). In 1994, the Yimchunger Nagas of the Fakim area south of Saramati reported seeing a 'dwarf' rhino ( $\mathrm{K}$. Thomas, pers. comm.). Some Nagas who occasionally visit the Hukawng Valley in northern Myanmar reported the occurrence of Sumatran rhino in that area also.

Both the Anko range and the Saramati areas are virtually inaccessible and are still covered with mature tropical and subtropical forests. Their inaccessibility and the presence of antigovernment rebels has saved them from the onslaught of illegal timber operators. Local Nagas are not averse to conservation measures as long as their normal economic activities are not hampered. Fortunately these activities are very limited and are confined to occasional trips by hunting parties and some movement along traditional tracks across the international border. (Nagas do not set out specifically to hunt rhinos, mainly because of the difficult terrain and extreme rarity of the animal, but some Nagas, especially from the western areas bordering Assam, are involved in poaching of Indian one-horned rhinos in Kaziranga and other areas.)

About $400 \mathrm{sq} \mathrm{km}$ in the Anko range of Manipur and about $500 \mathrm{sq} \mathrm{km}$ in the Saramati-Fakim area of Nagaland are strongly recommended as national parks or wildlife sanctuaries to save the wandering rhinos and their habitat. Fakim is already a notified wildlife sanctuary but covers only $6.4 \mathrm{sq} \mathrm{km}$ and is too small to protect sufficient habitat for viable populations of large mammals.

\section{Acknowledgements}

For their help during the field trip, I would like to thank the following people: in Manipur, Dr R. K. Ranjan Singh and other members of MASS (a local non-governmental organization), Aleng (the SDC [Magistrate] at Ukhrul); in Nagaland, Natwar Thakkar of Nagaland Gandhi Ashram, M. I. Bora (Deputy Commissioner of Zunheboto), Y. Lotha, K. Sohe and $\mathrm{K}$. Thomas (all of the People's Group, a local non-governmental organization), S. Hukiye (Head Gaonburha of Sakhalu, who was also a noted hunter). Special thanks are due to $\mathrm{Dr}$ S. Muivah and Ibohanbi Singh (both of MASS, Manipur), Akato Sema (EAC, Zunheboto), and Hakim (driver) for accompanying me to some of the remote areas of Manipur and Nagaland.

\section{References}

Cubitt, G. and Mountfort, G. 1985. Wild India. Collins, India.

Finn, F. 1929. Sterndale's Mammalia of India. Thacker, Spink and Co., Calcutta and Simla.

Harper, F. 1945. Extinct and Vanishing Mammals of the Old World.. Special publication. Am. com. Intern. Wildlife prot., 12; New York.

Khan, M. 1989. Asian Rhinos: An Action Plan for their Conservation. IUCN, Gland, Switzerland.

Lydekker, R. 1900. The Great and Small Game of India, Burma and Tibet. Rowland Ward, London.

Milroy, A.J.W. 1934. The preservation of wildlife in India. No. 3. Assam. J. Bombay nat Hist. Soc. 37 (Suppl.), 97-104.

Rabinowitz, A., Schaller, G. and Uga, U. 1995. A survey to assess the status of Sumatran rhinoceros and other large mammal species in Tamanthi Wildlife Sanctuary, Myanmar. Oryx, 29, 123-128.

Tilson, R. and Traylor-Holzer, K. 1993. Sumatran Rhino PHVA Briefing Book. IUCN/SSC Conservation Breeding Specialist Group, Minnesota.

Anwaruddin Choudhury

The Rhino Foundation for Nature in NE India c/o The Assam Co. Ltd, Bamunimaidam

Guwahati 781021

Assam, India 